This PDF is a selection from an out-of-print volume from the National Bureau of Economic Research

Volume Title: Social Security and Retirement around the World Volume Author/Editor: Jonathan Gruber and David A. Wise, editors

Volume Publisher: University of Chicago Press

Volume ISBN: 0-226-31011-6

Volume URL: http://www.nber.org/books/grub99-1

Publication Date: January 1999

Chapter Title: Social Security and Retirement in Japan

Chapter Author: Naohiro Yashiro, Takashi Oshio

Chapter URL: http://www.nber.org/chapters/c7253

Chapter pages in book: (p. 239 - 267) 


\section{6 \\ Social Security and Retirement in Japan}

Naohiro Yashiro and Takashi Oshio

While the aging of the population is a common feature in many industrial countries, the most striking feature in the case of Japan is the high speed at which the process is occurring. The reason for this is closely related to Japan's rapid economic development, which has triggered equally rapid social changes, namely, falling fertility ratios and rising life expectancies. As a result, the ratio of elderly people - usually defined as those who are age sixty-five or over - to the working-age population (aged twenty to sixty-four) rose from .10 in 1930 to .24 in 1995 and is projected to rise to .48 in 2025 . This will lead to a large expansion of social expenditures in the coming decades.

Japan's social security expenditures in 1994 amounted to $¥ 57$ trillion, which was 11.9 percent of Japan's GDP in that year, doubling its share of GDP in the past twenty years. Public pension benefits accounted for a large share of total social security expenditures (51.3 percent), followed by medical insurance benefits ( 38.2 percent). Public pension benefits also account for over 50 percent of the total family income of the average household whose head is age sixty-five or over. Thus, like other industrial countries, the benefit structure of the public pension program is likely to have important effects on the retirement decisions of older persons.

Nevertheless, there are several important characteristics particular to the case of Japan. One is the high household saving rate, which was 13.2 percent of disposable income in 1994, compared with 3.8 percent in the United States. According to opinion polls, the major incentive (even among older persons) to save is preparing for retirement. Another characteristic is the high level of labor force participation (LFP) of older persons. The average labor force participa-

Naohiro Yashiro is professor of economics at the Institute of International Relations at Sophia University. Takashi Oshio is professor of economics at Ritsumeikan University.

The authors thank David Wise, Jonathan Gruber, and seminar participants for helpful discussions. 
tion ratios of males aged sixty to sixty-four and sixty-five to sixty-nine were 75 and 54 percent, respectively. The high labor force participation of older persons in Japan is one factor behind the high levels of household saving as it is likely that people continue to save as long as they work. To what extent these high ratios of both labor force participation and savings on the part of older persons in Japan are affected by the social security system remains a source of much controversy.

The purpose of our paper is to provide an overview of the interaction between social security (in particular, the public pension scheme) and the labor force behavior of older persons in Japan. The structure of the paper is in line with that of Diamond and Gruber (chap. 11 in this volume), who conduct a similar study for the U.S. social security system. In section 6.1 , we examine several key features of the labor market behavior of older persons with specific reference to the recent reversal of the previous trend toward earlier retirement. ${ }^{\prime}$ In section 6.2, we describe the basic structure of the public pension system in Japan, focusing on the recent major changes in the institutional details concerning retirement behavior. In section 6.3, we estimate the social security wealth of the average employee in Japan and document the retirement incentives inherent in the current social security system. Finally, we discuss several country-specific social security and labor market issues that are closely related to social security wealth.

\subsection{The Labor Market Behavior of Older Persons}

One of the common features in the labor markets in many OECD countries in the postwar period, including Japan, has been the declining participation of older persons. In 1960, almost 70 percent of men aged sixty-five to sixty-nine were participating in the labor force. By 1997, this figure had fallen to 53 percent-a figure that is nevertheless still high by international standards. There are various factors affecting these declines in labor market participation, among which improvement in social security benefits is significant. In this section, we provide some background on the labor market behavior of older persons.

\subsubsection{Historical Trends}

Figures 6.1 and 6.2 show the historical trends of the labor force participation rates of men and women from 1960 to 1996, respectively. For men, the labor force participation rates of those aged sixty to sixty-four and sixty-five and above declined, while the rate for those aged forty-five to fifty-nine was virtually flat. For women, the pattern is quite different-for age groups younger

1. What retirement means in Japan is usually retirement from the primary firm in which one used to work for a long time and not necessarily retirement from the labor market per se. Many older Japanese persons continue to work after mandatory retirement from the primary firm, moving to smaller firms with no mandatory retirement but less favorable working conditions. 


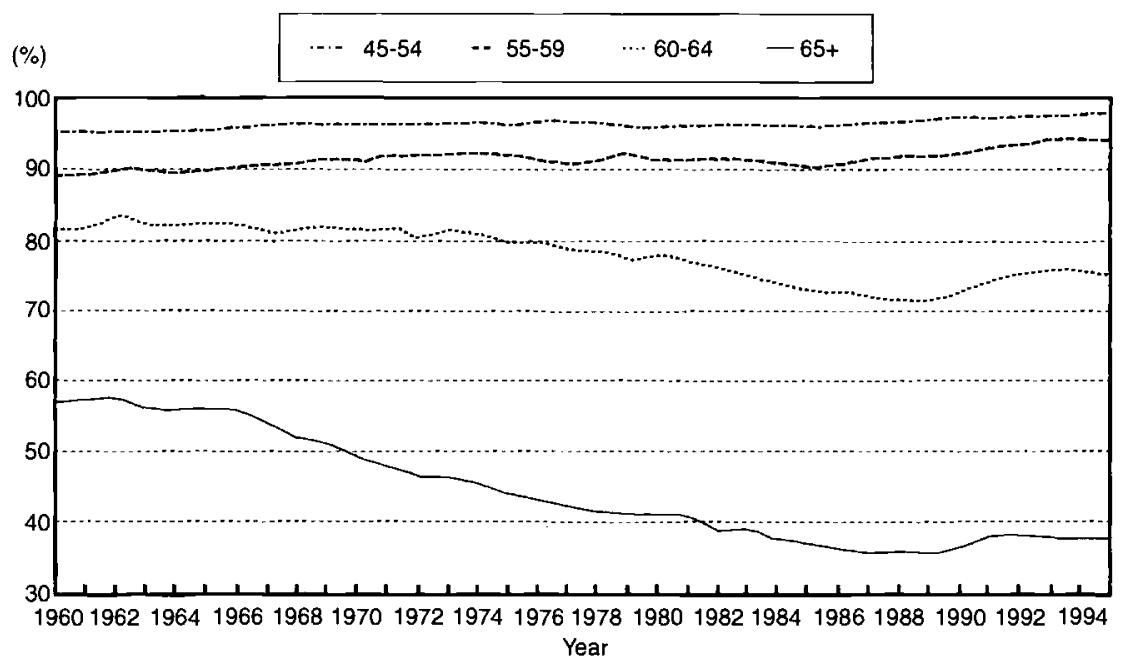

Fig. 6.1 Historical trends of labor force participation rates of men

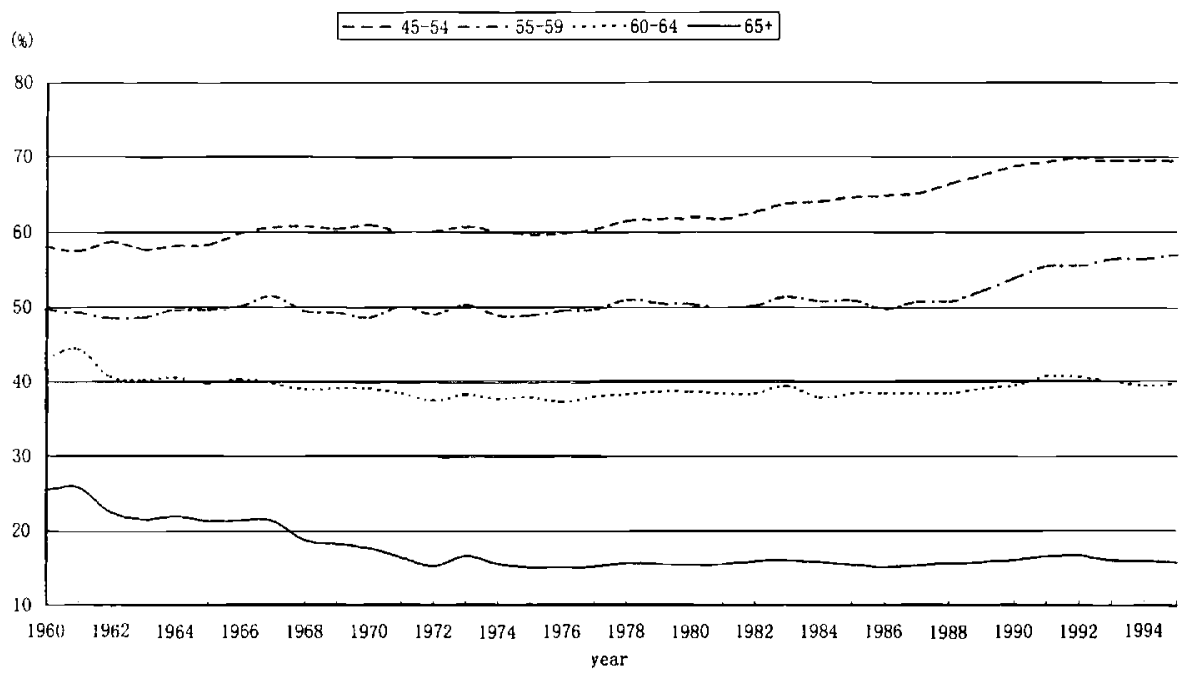

Fig. 6.2 Historical trends of labor force participation rates of women

than sixty, labor force participation increased, while, for age groups over sixty, the trend toward earlier retirement dominates-although the changes are much less pronounced than in the case of men.

This decline in the labor force participation rates of older persons in Japan is mainly due to the declining share of the self-employed and improved pension benefits. In the postwar period, the share of the self-employed (including un- 
paid family workers) among total workers fell from 47 to 18 percent between 1960 and 1996. This is mainly due to the decline of the agricultural sector and the migration of the population from rural to urban areas. However, in 1996, the share of the self-employed among total employment was still 35 and 57 percent in the age groups sixty to sixty-four and sixty-five or above, respectively, partly accounting for the high labor market attachment of older persons. As the average labor market participation of the self-employed is higher than that of employees, the shrinking self-employed sector is one factor behind the falling average labor force participation ratios. Another factor behind the decline in labor force participation is an increasing trend toward greater pension benefits (see below).

As for the participation ratio in the pension plans, enrollment in a public pension plan is compulsory for everyone in the workforce, including the selfemployed. However, whereas the social security premiums of employees are automatically deducted from wages along with taxes, about 30 percent (excluding those who are exempted from paying premiums) of the self-employed and other nonemployees do not participate in a pension plan, a situation due mainly to the lack of an enforcement mechanism. Also, the public pension benefits of the self-employed have little effect on their labor force participation. This is because eligibility for benefits is not linked to retirement and because pension benefits are granted at age sixty-five and are not means tested. Also, the average benefit level is approximately one-quarter that for employees. The pension benefits of employees, however, are significantly higher and are subject to an earnings test. Thus, with the rising share (53 percent of all workers in 1960, 84 percent in 1996) of employees, who are more affected by public pension policies, public pension benefits figure more importantly in the retirement decisions of older Japanese workers (fig. 6.3).

\subsubsection{Reversal of the Trend toward Earlier Retirement}

Another interesting feature of the labor force participation of older persons in Japan is the fact that the long-run pattern of decline reversed between 1988 and 1993 and that participation thereafter remained steady at its 1993 level. This is particularly prominent among men aged sixty to sixty-four, but a similar pattern is observed for the group aged sixty-five or over, too (see fig. 6.1 above). Although many attribute older people's high levels of labor market participation in Japan to such supply-side factors as insufficient social security benefits, such factors do not plausibly explain the reversal of the trend as Japan's social security benefits have not declined in comparison to earnings over time. A key cause of the reversal lies in demand. If we compare the labor force participation of men aged sixty to sixty-four and the unemployment rate of the same age group, reflecting the tightness of the labor market for older persons, the period of the increase in labor force participation also saw a falling unemployment rate. Estimating the labor force participation of men aged sixty to 


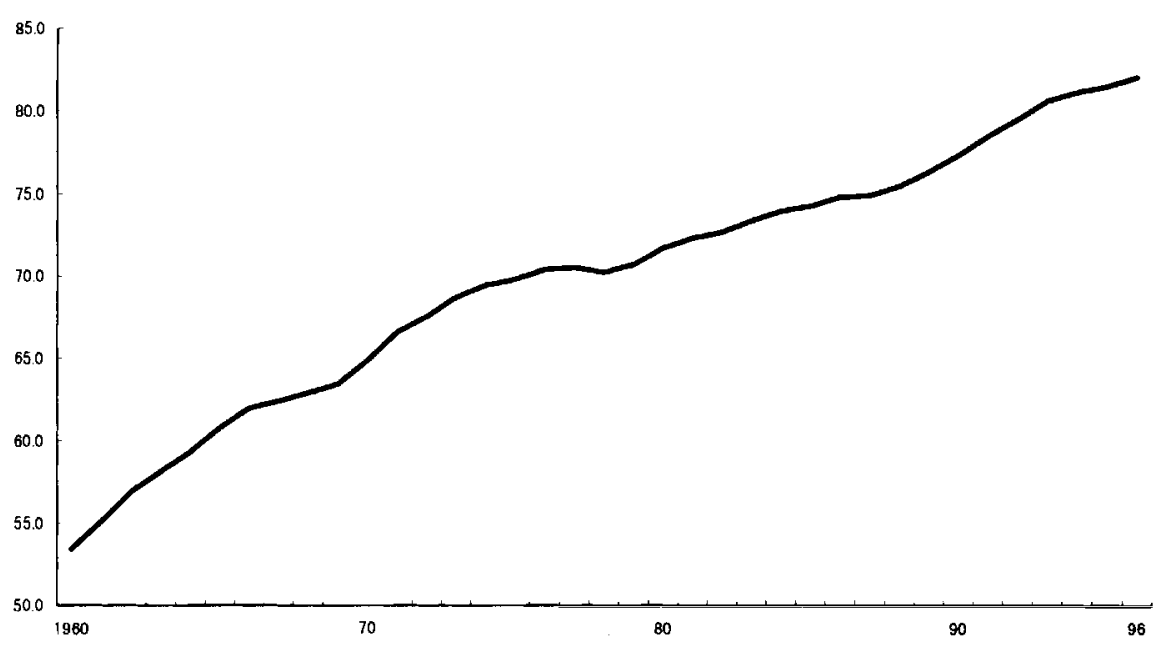

Fig. 6.3 Share of employees in total employed

sixty-four by adding the corresponding unemployment rate to the average replacement ratio resulted in a better explanation of rising labor force participation in the late 1980 s (fig. 6.4). ${ }^{2}$ While the strong demand for employment resulting in the rising labor force participation of older persons in the late 1980s was mainly due to cyclic factors, such demand may well be seen again in the near future. This is because the size of the working-age population (between the ages of fifteen and sixty-four) has already started to shrink as of 1995, and this trend is projected to continue through the twenty-first century: with a constant labor force participation rate for each age group, Japan's labor force will decline by 7.6 percent in 2020 from the 1993 level. This overall decline in the labor force may well stimulate the labor force participation of older persons by providing them with good job opportunities.

Figure 6.5 indicates social security replacement rates over time. The replacement ratio here is defined as the ratio of the monthly pension benefits of a married couple in the representative public pension scheme for private-sector

2. The OLS estimated results with and without the unemployment rate are as follows:

$$
\begin{aligned}
\text { LFP }= & 88.18-0.311 \text { replacement ratio, } R^{2}=.0775 \\
& (46.64)(-10.83) \\
\text { LFP }= & 86.37-0.0852 \text { replacement ratio }-1.896 \text { unemployment rate, } R^{2}=0.884 . \\
& (62.74)(-1.87)
\end{aligned}
$$




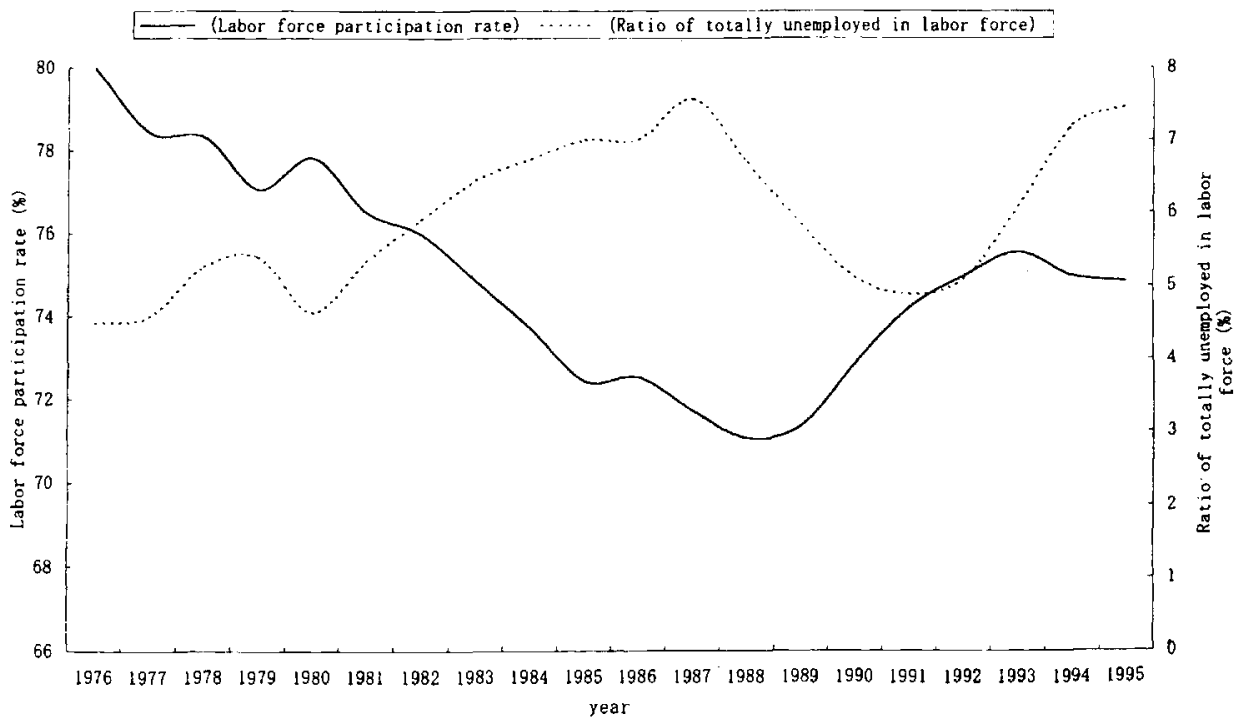

Fig. 6.4 Labor force participation of men aged 60-64 and unemployment rate

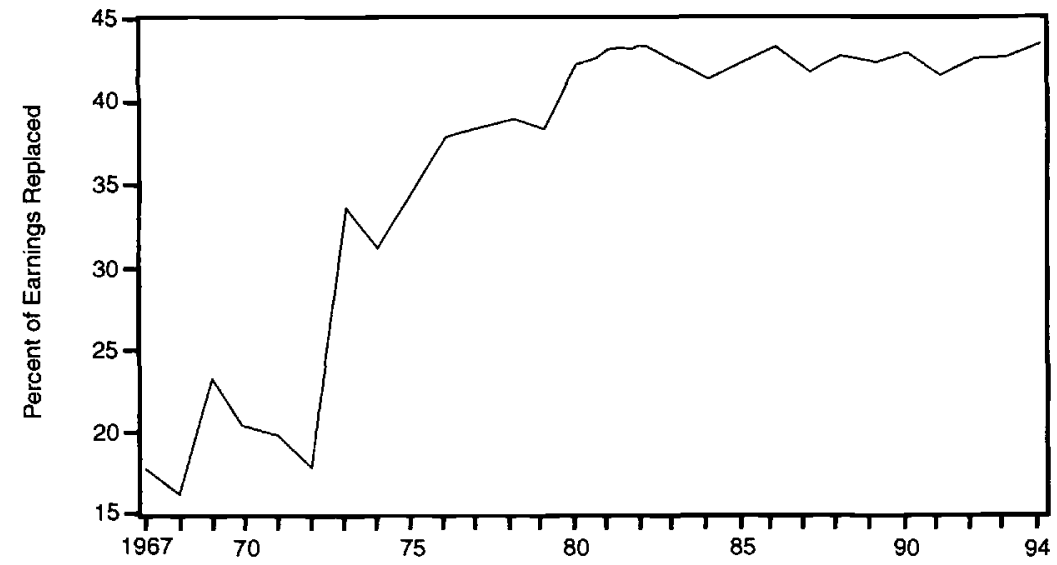

Fig. 6.5 Social security replacement rates (monthly earnings including bonus)

employees to average monthly earnings, including biannual bonus payments. There was a sudden jump in 1974 when the public pension scheme was reformed, including the introduction of wage indexation, resulting in a doubling of benefits in subsequent periods. After the 1980s, the replacement rates have increased steadily over time. 


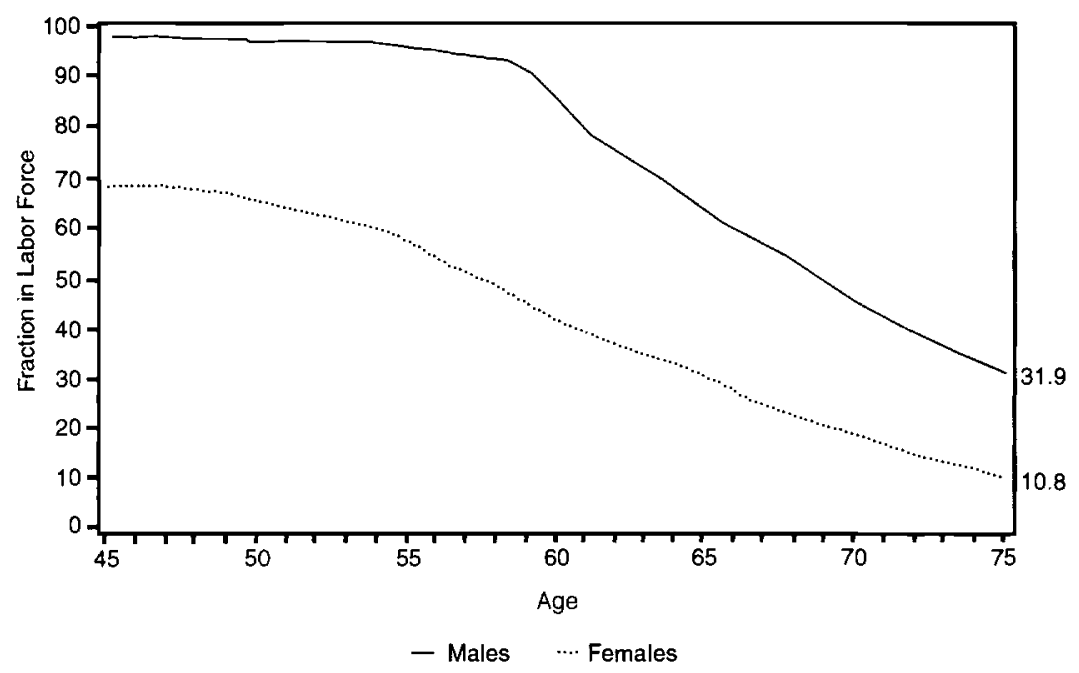

Fig. 6.6 Participation rates by age and sex (\%)

\subsubsection{Recent Labor Market Behavior}

To obtain a more detailed understanding of the time pattern of labor force participation in recent years, we use the national census data for 1990. The national census asks all individuals in the country about their labor force participation at the time the survey is conducted. Also, this is the only survey that publishes labor force participation data broken down by age-by-age changes.

The age pattern of participation for men and women is shown in figure 6.6. At age forty-five in 1990, the participation rate of men is close to full capacity, while only 70 percent of women worked. There is then a gradual decline for men until age fifty-five, at which point the pace accelerates. There is a sharp drop in participation at age sixty, which is the typical mandatory retirement age for major Japanese firms. But even after the mandatory retirement age, labor market attachment is relatively strong, and 32 percent of males still work even at age seventy-five. It should be noted that, among elderly males, the share of the self-employed who are voluntary part-time workers is much higher than the male average ( 16 percent), accounting for 34 and 47 percent of total employment for the age groups sixty to sixty-four and sixty-five to sixty-nine, respectively. This implies that the actual capacity of human resources at older ages in Japan may well be overestimated if one accounts for their shorter working hours. Participation falls more rapidly for women in their fifties than it does for men, although the pace is almost unchanged up to the eighties, with the result that the participation gap between the genders closes beyond age sixty. As most older women in the labor market are self-employed, the mandatory retirement system affects the participation of women much less than it does that of men. 


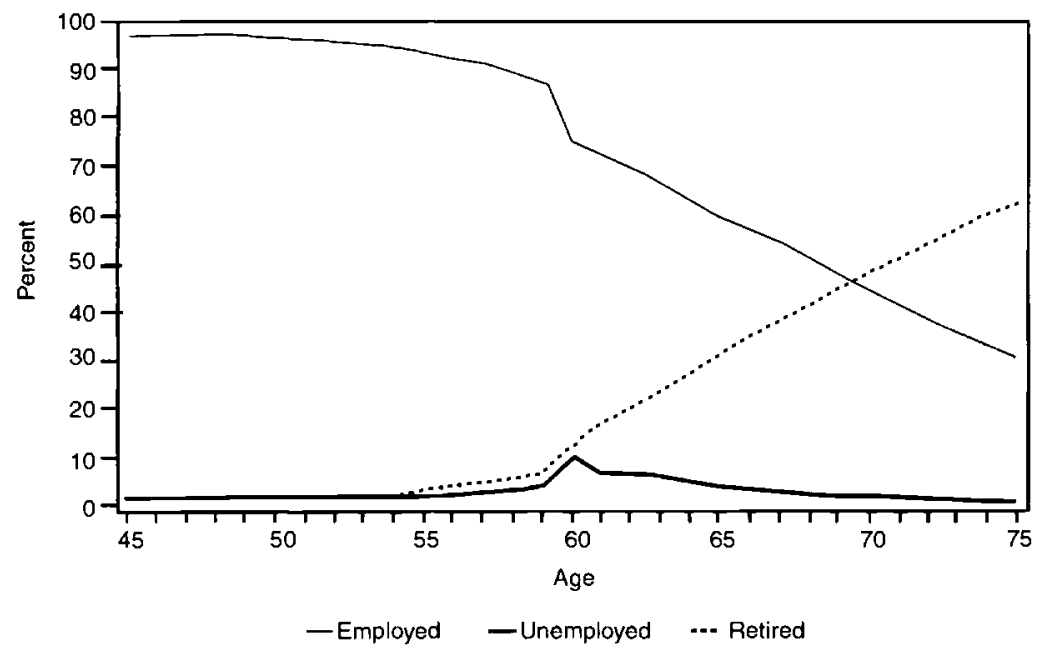

Fig. 6.7 Distribution of activities of men by age (\%)

Figure 6.7 shows in more detail the allocation of time among men as they age, dividing their activity status into employment, unemployment, and retirement. From the available statistics, it is difficult to determine whether those who are not in the workforce are retired or simply not working. Thus, retired persons are considered to be those who are not in the labor force and do not either engage in household work, go to school, and seek jobs. This same exercise is repeated for women in figure 6.8. Particularly to be noted among Japanese women aged forty to fifty is the high ratio of homemakers; they account for a substantial portion even at age sixty and beyond.

\subsubsection{Income Sources of Older Persons}

In figure 6.9, we examine the public retirement incomes of older persons on the basis of the Basic Survey on People's Life, conducted by the Ministry of Welfare. The figure shows the rate at which public pension and other public assistance mainly from the income maintenance program is received. Beginning at age sixty, the rate of collection of social security benefits increases sharply, driven by the collection of the public pension, until it is over 90 percent for those over age sixty-five. Private pensions are not popular in Japan, partly because there are few tax incentives to encourage enrolling in such pensions. On the contrary, large lump-sum severance payments made at the time of retirement, a substitute for the firm pensions offered in the United States, play an important role in saving for retirement (for details, see the section below on country-specific practices).

Private pensions have become an important source of retirement income. The size of the accumulated assets of private pensions in the financial markets 


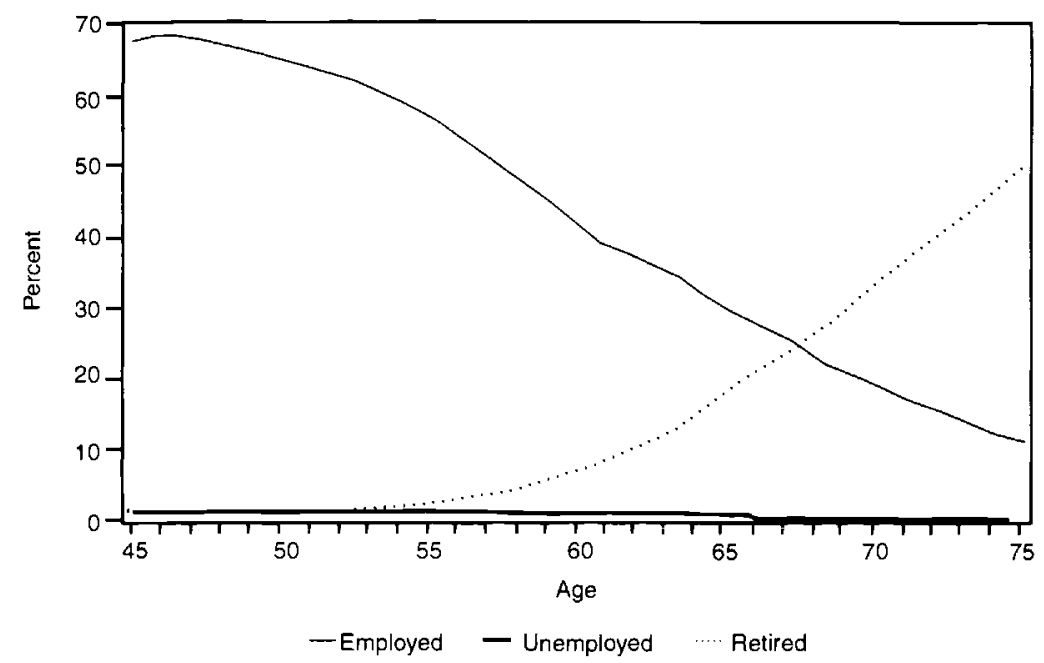

Fig. 6.8 Distribution of activities of women by age (\%)

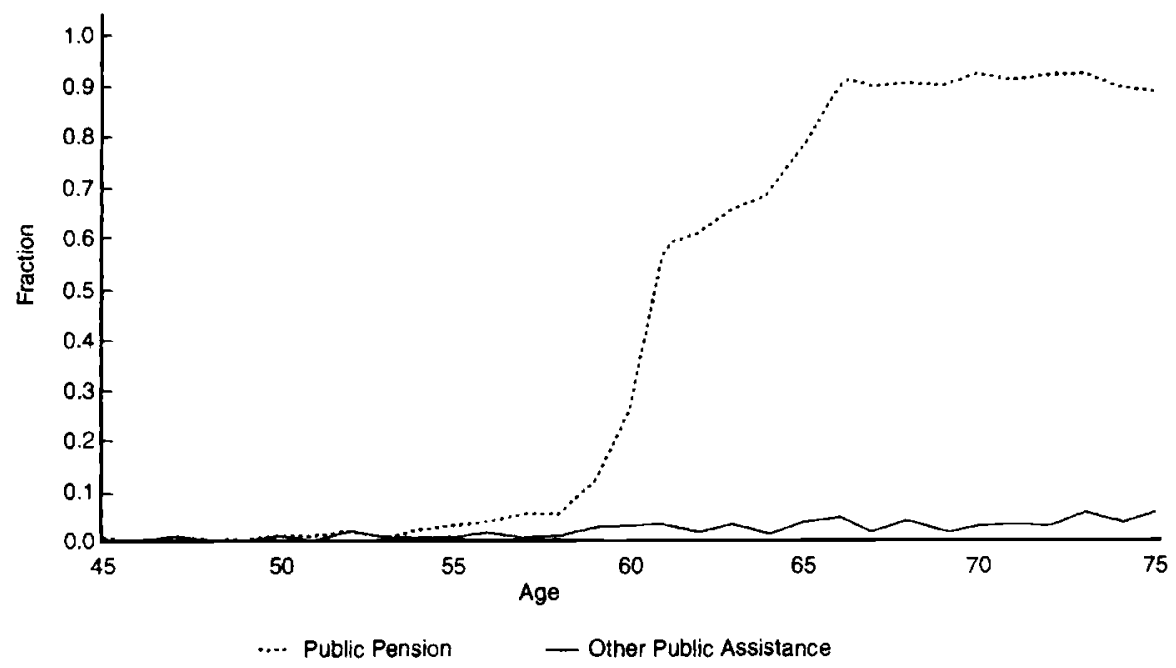

Fig. 6.9 Public income recipiency for men

exceeded that of firm pensions in the 1990s even though the tax benefits are quite limited. While the official data on private pensions are scant, an ad hoc survey based on a small sample by the Ministry of Post and Telecommunication indicates that the ratio of families having private pensions has risen over the last few years (fig. 6.10).

Finally, figure 6.11 shows the distribution of income sources of individuals 


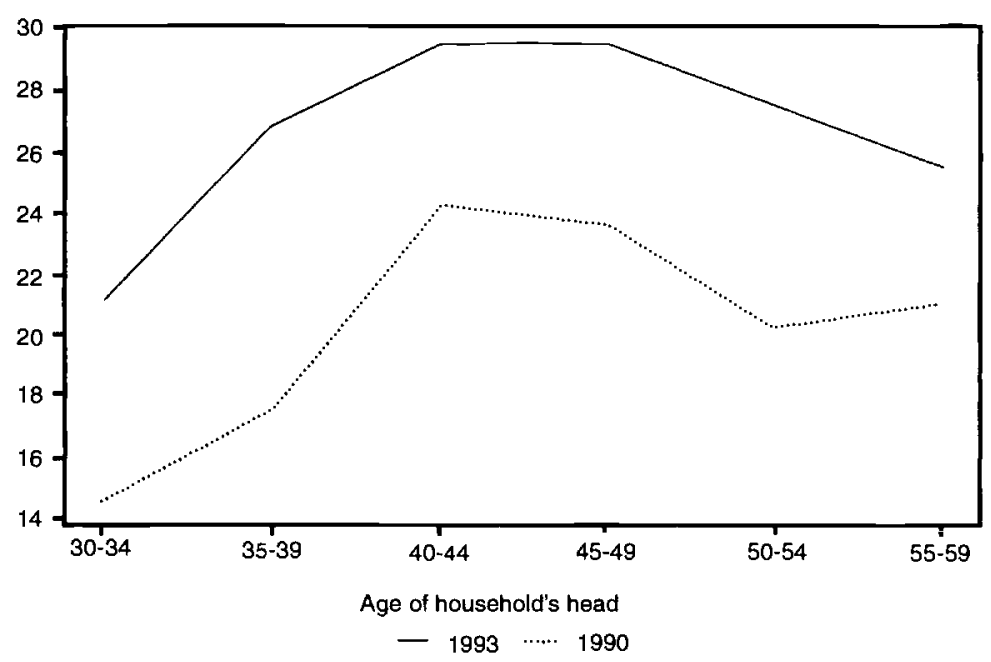

Fig. 6.10 Participation ratio of families to private pensions

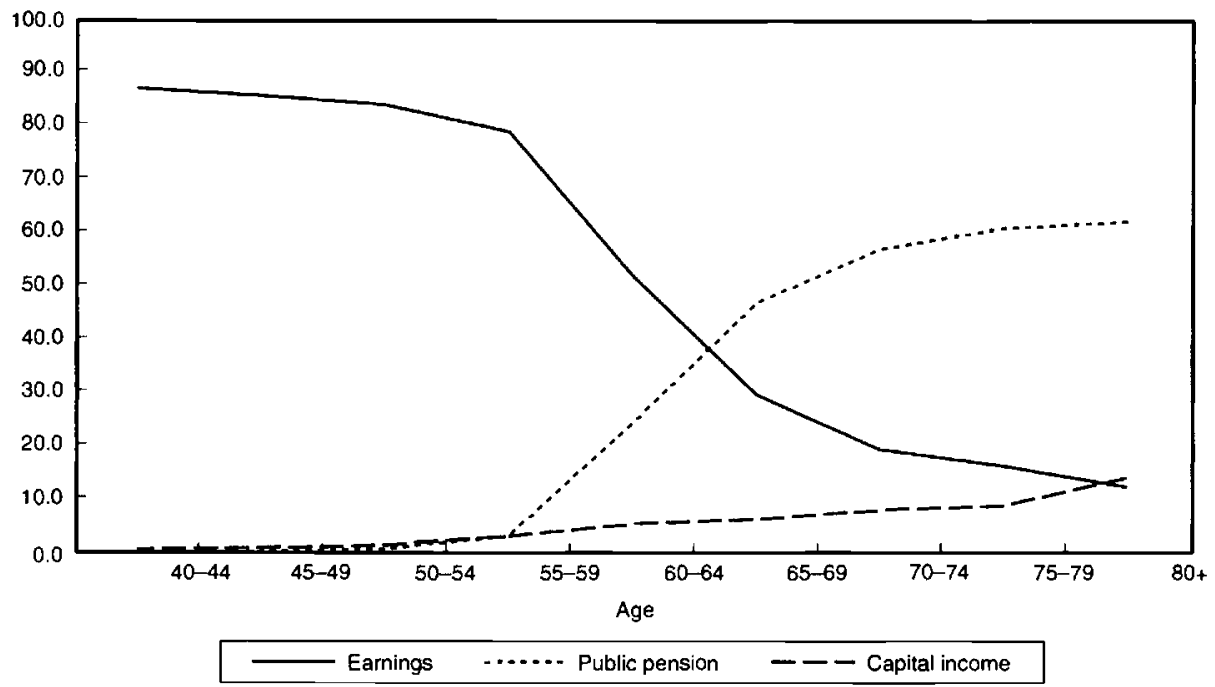

Fig. 6.11 Distribution of income by source

between the ages of forty-five and seventy-five on the basis of the Basic Survey on People's Life. We consider the distribution of income across three sources: earnings, capital income, and public pensions. Earnings are the dominant source of family income until age sixty, accounting for about 80 percent of total household income. Beginning at age sixty, earnings decline, and public pensions grow as a major source of the income of the elderly, accounting for 
about 80 percent of the total. It should be noted that these data on the incomes of elderly individuals are not available from the conventional household surveys, which are based on the age of the household's head. More than half the elderly age sixty-five or over live with their relatives, including their children's family, and the ratio is particularly high for the poor elderly. Thus, those who are economically dependent on their children tend to drop from the household surveys, leaving the relatively rich elderly as the head of the household in statistics (Yashiro 1997). Also, even when an elderly individual maintains the position of the household's head, the inclusion of children's earnings in the family income may underestimate the role that pension benefits play in the total income of the elderly. Thus, an international comparison of the economic position of the elderly needs to account for the difference in family structure.

\subsection{Key Features of the Social Security System}

\subsubsection{A History of the Social Security System in Japan}

The current public pension for private-sector employees originated from the Rodosha Nenkin Hokenhou (Pension Insurance for Workers) Act in 1942, following the establishment of the National Health Insurance Act of 1938. Although the major purpose of social security insurance was to secure workers' standard of living, such extensive social security reform was possible only in wartime, when the government needed all the manpower it could muster in exchange for an assurance that minimum living standards would be maintained.

Japan's social security program, which consists of public pension and health insurance schemes and covers everyone, including those who are selfemployed or not working, was established in 1961. Since then, the size of social security expenditures increased at a much faster pace than did the economy as a whole, growing from 4.9 percent of national income in 1960 to 14.1 percent in 1996. A major reform of social security occurred in 1973. The pension reform included the introduction of automatic increases in benefits with increases in inflation and wages: monthly pension benefit levels are set at 60 percent of wages when the funding scheme is fully matured, and revaluation of the benefit levels occurs every five years; benefits are also adjusted annually to keep pace with increases in the CPI. Also, there is a scheme providing special benefits for the elderly who have not contributed long enough to receive pension benefits. On the other hand, the health insurance scheme was also reformed mainly to improve benefits. Medical costs covered by health insurance have increased from 50 to $70-90$ percent of the total. Also, 100 percent of expensive medical care is covered by the insurance, and those aged seventy and above are covered by separate health insurance, under which medical services are provided at minimal fixed cost.

However, 1973 also saw the oil price hike and a deceleration of economic 
growth, ending the high-growth period of 10 percent average annual economic growth prevailing since the early 1950s. Moreover, the total fertility ratio started to decline again in 1975 , from about 2.1 to 1.4 in 1996 , while male and female life expectancy at age sixty-five has increased substantially, from 13.7 and 16.6 years to 16.7 and 21.0 years, respectively. Both economic and demographic factors have worked against the social security fiscal balance by reducing the number of contributors and increasing beneficiaries and placing strong pressure on the system in the form of increasing fiscal deficits.

The most recent public pension reform in 1994 was meant to mitigate the demographic pressure on the social security program. First, pension premiums are to be raised to a level slightly lower than 30 percent of monthly wages by the year 2025. Second, pension benefits are linked not to gross wages but to wages net of taxes and social security premiums; that is, the higher the taxes and social security premiums imposed on the working generation, the lower the pension benefits of the retired, thus balancing the equality between the generations. Third, the eligibility age for the flat pension component of the employees' pension is scheduled to be raised from the current sixty to sixtyfive beginning in 2001 , one year every three years.

\subsubsection{Major Features of the Public Pension Scheme}

Japan's public pension scheme consists basically of two pillars: one is the basic pension mainly for the self-employed and other nonemployees; the other is for employees in both the public and the private sectors. The pension benefits for employees consist of two parts: the basic pension, which they have in common with the self-employed, and the earnings-related pension.

The basic pension is mainly for the self-employed, unpaid family workers, and nonworkers (the unemployed, students age twenty or over, homemakers). It is a simple scheme based on a flat tax and a flat benefit structure, and it is managed by local authorities. It is organized on an individual-unit basis-that is, both husband and wife pay premiums and receive benefits individuallythus, there are benefits for neither dependent spouses nor survivors. The eligibility age is sixty-five, but one can collect the benefits as early as age sixty with a certain reduction in rates. The basic pension has little effect on retirement decisions mainly because the benefits are relatively small (the average benefit was $¥ 43,000$ per month in 1995). Benefits are not subject to any earnings criteria.

On the other hand, the pension schemes for employees are organized on a family-unit basis, and dependent spouses are covered by the pension of the head of the household. In addition, dependent spouses are provided as individuals with the basic pension from age sixty-five and survivor pension benefits, equivalent to two-thirds of the full pension. The earnings-related pension is designed to maintain an individual's standard of living after retirement, and payments are proportional to contributions related to wages in the past, subject to a certain ceiling. The average amount of the benefits was $¥ 168,000$ per 
month in 1995. Unlike the pension scheme for the self-employed, the employee pension can greatly affect the retirement decision of an individual, particularly at age sixty to sixty-four, when the benefits are reduced on the basis of amount of earnings. Thus, in the following sections, our discussion will center around the pension schemes for employees.

\subsubsection{Pension Schemes for Employees}

There are eight public pension schemes covering various types of employees, and the Kosei Nenkin Hoken (KNH, Employees Pension Insurance) dominates as the largest public pension scheme for private-sector employees, covering 85 percent of all employees. Thus, we use the $\mathrm{KNH}$ to represent the earnings-related pension for employees. The public pension for employees is financed by premiums that are paid by employees and employers in equal proportions, and the total premium paid was 16.5 percent of monthly wages ${ }^{3}$ in 1995 (i.e., the employee and the employer paid 8.25 percent each).

An additional contribution of 8 percent of monthly wages is devoted to health insurance for private-sector employees. The social security fund, consisting mostly of pension funds and the surplus, equivalent to 3.5 percent of GDP in 1995, receives interest from the Fiscal Investment and Loan Program (FILP). ${ }^{4}$ In addition, there are government transfers financed by general taxes equivalent to one-third of the total benefits of the basic pension and administrative expenses. Although the public pension fund is subsidized by the central government, its budget is kept completely separate from the general budget, and the surplus in the pension fund cannot be used to reduce the government deficit.

Eligibility for a public pension is based on age. All individuals between twenty and fifty-nine years of age are obliged to participate in their respective public pension programs. Most of the contributions (and income taxes) are automatically deducted from wages by the company, except in certain small firms. However, those aged sixty and over are not automatically qualified to enroll in a public pension scheme even though they may continue to work. ${ }^{5}$ Individual pension assets can be transferred to other schemes when one changes jobs, as in principle an individual is eligible to receive only one pension.

\subsubsection{Pension Benefits}

An individual's benefit amount is determined by the following steps. A worker's monthly wages (excluding semiannual bonuses) are converted into

3. The monthly standard wage excludes semiannual bonuses, accounting for a quarter of annual earnings. The replacement rate of pension benefits to annual earnings is slightly below 50 percent, which is on a comparable basis to that prevailing in other OECD countries.

4. FILP is the government financing program directed mainly at public infrastructures supported mainly by funds from the public pension funds and postal savings. FILP has played an important role in providing funds for social capital, particularly during the high-growth period.

5 . Even after age sixty-five, an individual can voluntarily contribute to the earnings-related pension unless he already receives pension benefits. 
hyoujun houshuu getsugaku (HHG), the standard average monthly earnings), indexed by the national wage average. HHG is divided into thirty brackets that range from $¥ 92,000$ to $¥ 590,000$. This wage history is averaged over the employee's entire period of coverage up to age sixty-four. A particular characteristic of the Japanese pension system is that the total length of the contributing periods for the earning-related portion of the $\mathrm{KNH}$ is not fixed (regardless of how many years one has worked) and that only a limitation on age (age sixtyfive) exists. ${ }^{6}$

In this sense, the additional years' work plays an important role in increasing the benefits in the earning-related component of the employee's pension. For example, a worker who left his firm at age sixty and continues to work in another firm at much lower wages can still increase his pension benefits as the positive effect on the pension benefits from an additional year of work will more than offset the negative effect arising from the lowered average contribution.

Workers can claim KNH benefits at the normal retirement age of sixty-five, before the full pension is granted at age sixty-five. Between the ages of sixty and sixty-four, the payment of pension benefits is subject to an earnings test (see below). Beyond age sixty-five, the recipient is eligible to receive the full pension with no earnings test and has the option of delaying receipt of the full pension. For workers reaching age sixty-five in 1996, an additional 12 percent of pension benefits is paid for each year that the collection of benefits is delayed. This amount will steadily increase until the additional rate reaches 88 percent at age seventy.

\subsubsection{The Zaishoku (Early Retirement) Pension}

While one can claim the zaishoku pension benefits as early as age sixty, the receipt of social security benefits is conditional on passing the "earnings test" on wages (but not on other income or assets) until age sixty-five. This scheme corresponds to the early retirement systems in many other OECD countries. That is, if one earns more than a certain floor level, social security benefits $\left(\mathrm{PEN} W_{t}\right)$ are reduced for each additional dollar of earnings $\left(W_{t}\right)$ until, at high earnings, one may not qualify at all. For example, if an individual earns even a small amount, the benefits are automatically reduced by 20 percent. Benefits are reduced for any earnings above $¥ 220,000$ per month by 50 percent of the full pension benefits (PENF60) for each additional increment of earnings. Benefits are reduced by 100 percent for anyone who earns more than $¥ 340,000{ }^{7}$ The formula is

6. There is a maximum number of years of contributions-forty-in the flat pension for the self-employed.

7. This rate of reduction of pension benefits with higher wages has been lowered substantially since 1995 to prevent it from acting as a disincentive for older workers, but a de facto 50 percent effective income tax still remains. 


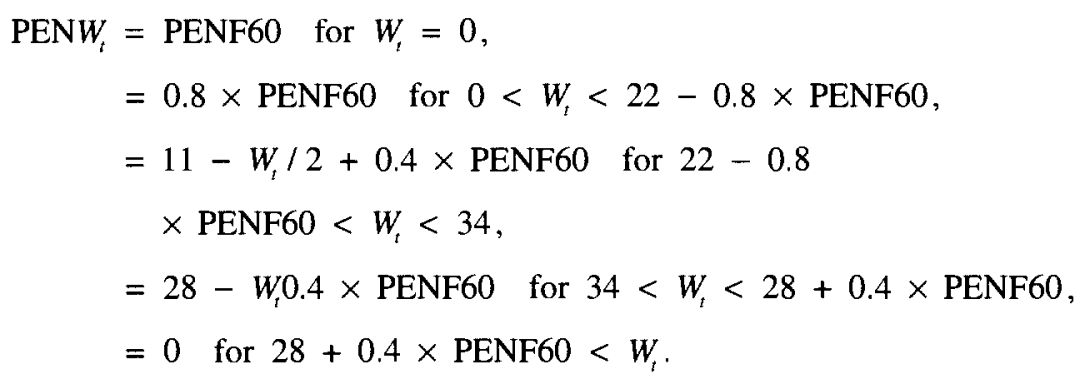

These thresholds on the earnings test increase every five years with average earnings in the economy.

\subsubsection{The Full Pension}

The full $\mathrm{KNH}$ pension for which one is eligible at age sixty-five is generous by international standards. First, the pension benefits are not subject to an earning tests, and even full-time workers can receive full pension benefits. Second, no contributions from the earnings of those age sixty-five and over are required even if the individuals concerned are working full time. Third, income tax law favors pension benefits over earnings, and most benefit recipients are exempt from income taxes. Thus, receiving full pension benefits at age sixty-five does not exert much influence on retirement decisions.

\subsubsection{Benefits to Dependent Spouses}

There are additional pension benefit provisions for those who have dependent families. Dependent spouses of social security beneficiaries receive additional benefits: the kakyu (a supplementary pension), the dependent spouse's own basic pension, and survivor benefits. ${ }^{8}$ First, kakyu pension benefits for the dependent spouse are $¥ 226,000$ per year; the same amount is provided for the first two dependent children under the age of eighteen and $¥ 75,300$ for any younger children. ${ }^{9}$ Second, dependent spouses are entitled to their own basic pension from age sixty-five with no additional contributions, unlike singles or economically independent spouses with the same income levels. This measure protects dependent spouses who divorce at older ages and have no individual pension on which to rely. Third, surviving spouses receive three-quarters of full pension benefits, beginning at age sixty. Dependent children, parents, grandchildren, and grandparents are eligible for these benefits as well.

The situation involving dependent spouses who have their own earnings is somewhat complicated because they therefore are entitled to pensions based

8. A dependent spouse is one who earns less than $¥ 1.3$ million annually and is not obliged to pay premiums.

9. The frikae (replacement) pension benefit is replaced by the kakyu pension when dependent spouses reach age sixty-five. The kakyu pension benefit is a temporary provision for older persons and is subject to a reduction in rates based on year of birth. The more recently the spouse was born, the less she receives, and those born after 1965 receive nothing. 
on their own contributions. Economically independent spouses are obliged to choose between survival benefits and their own pension benefits. Since 1995 , however, they have had the option of receiving half of each. ${ }^{10}$ This raises equality issues about possibly significant differences in the lifetime pension benefits collected by workers who have the same level of earnings but who may or may not have dependent spouses because, beyond a certain income ceiling, they lose various pension benefits granted to nonworking homemakers. In addition, the system may well discourage dependent spouses from working full-time. Indeed, several studies indicate that dependent spouses deliberately restrain their annual earnings in order to maintain their status (Higuchi 1995).

\subsubsection{Disability Pension}

The disability pension is the income that workers physically unable to participate in the labor market will receive to sustain their standard of living. Those who qualify for the disability pension are eligible to receive benefits regardless of age after age twenty. The benefits are calculated in a similar way to retirement pensions, and additional benefits of 25 percent are provided to those who are considered to have a major disability. Also, one can collect a disability basic pension amounting to $¥ 785,500$ per year regardless of the length of contributing periods. One can choose either of two disability pensions.

In $1994,285,000$ people received a disability pension ( 3 percent of old age pension recipients), and the average benefit was $¥ 102$, 000 per month (60 percent of average old age pension benefits). Eligibility conditions for the disability pension are strict. Most disabilities must originate in injuries, and physical disabilities that occur with aging are not sufficient. Thus, in Japan, disability pensions cannot be used to finance earlier retirement, as such pensions can be in several European countries.

\subsubsection{Hazard Rate}

An effective indicator of the effects of the country-specific social security system on labor force participation trends is the "hazard rate" out of the labor force for men and women. This is measured as the increase from the previous age of those leaving the labor force relative to the stock of workers participating at the previous age. However, this indicator is susceptible to age-by-age population changes and is not an appropriate measure to use when examining the exit pattern of older persons in Japan.

Thus, we show instead an alternative hazard rate out of the labor force in terms of participation rates - the percentage point changes in the participation rates from the previous year-for men and women (fig. 6.12). We see a large

10. A rationale for this adjustment is that both survivor benefits and own pension benefits are subsidized by the government and receiving two subsidies instead of one is considered unfair. Households in which both husband and wife work were not nearly as prevalent at the time the earnings-related pension was first developed. 


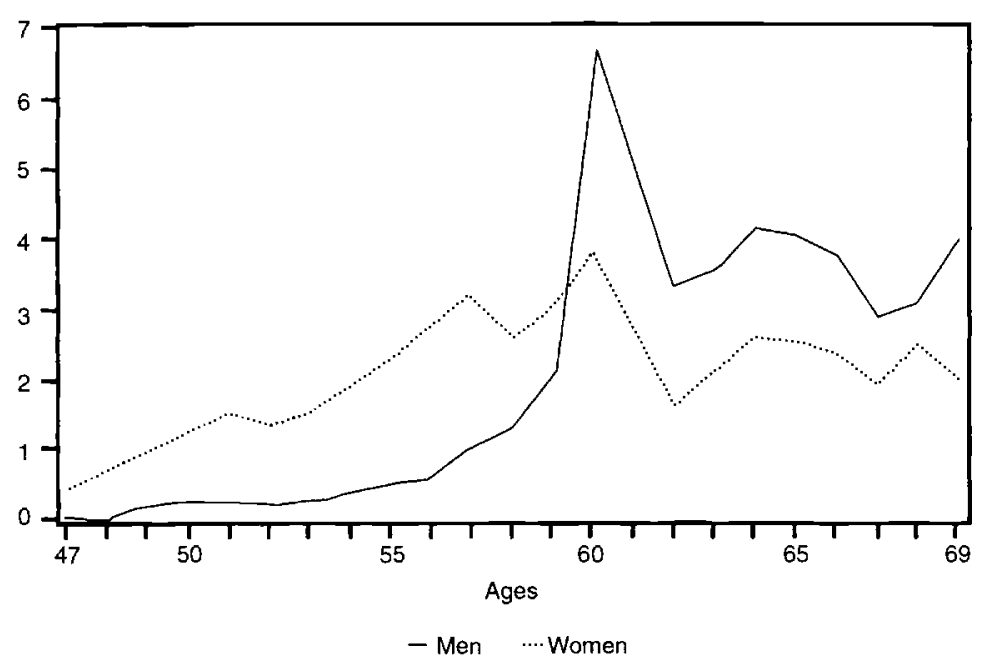

Fig. 6.12 Hazard rate out of the labor force (differences in labor force participation ratio)

jump at age sixty for men. This is obviously the result of the general practice of mandatory retirement. However, it also suggests that social security has a role in explaining the retirement behavior of men as sixty is the age of eligibility for the earlier retirement social security benefit, just as in the United States. In addition, there is another jump at age sixty-five, which corresponds to the eligibility age for receiving the full pension benefit without the earnings-test criteria. On the other hand, because many women in their fifties are part-time workers and social security benefits do not work as retirement incentives for older women, the jump at age sixty is less pronounced for women since retirement for women rising consistently through the fifties.

\subsection{Survey of Previous Studies}

Few empirical studies have been conducted in Japan concerning the interaction between social security benefits and retirement. This discussion draws on Takayama (1992), Seike (1993), and Tachibanaki and Shimono (1994). First, Takayama (1992) used the micro-data set from the National Survey on Family Income and Expenditure (1984) to estimate pension wealth and analyze the redistributional effects of the public pension. Takayama (1992) also examined the probability of retirement for dependent employees with various classes of pension benefits in the age group sixty to sixty-four, finding a significant negative relation. Moreover, the marginal effect of an increase in benefits on retirement is large for individuals at the low end of the benefit range. Similar results have been obtained by Tachibanaki and Shimono (1994).

Second, Seike (1993), following previous work by Ward (1984), estimated 
the pension wealth of an average employee having a dependent spouse and its annual changes. He found that changes in pension wealth as a proportion of annual earnings before retirement became negative at age sixty, when pension benefits are provided. This is consistent with a large drop in labor force participation. However, as Seike conceives social security wealth, premiums are not subtracted. Also, the expected value of the survivor pension is not taken into account as his concept of pension wealth is individual based, compared with ours, which accounts for the expected benefits of the wife. Further, there is room for argument as to the extent to which the concept of social security wealth should be broadened; we take a wider view, one that accounts for various factors affecting the retirement decision of an individual, including wage subsidies specific to the age group sixty to sixty-four.

\subsection{Retirement Incentives}

In this section, we use a representative household to assess the incentives of social security benefits on retirement through accrual rate effects; we also test variations under alternative assumptions. A major reform of the Japanese public pension scheme was introduced in 1994 , but in this section we analyze the effects of the situation prevailing before the 1994 reform, postponing discussion of the effects of the 1994 reform until the country-specific analysis provided in section 6.5 below.

\subsubsection{Modeling Social Security Benefits}

In Japan, the Social Security Administration's official data that record the individual history of wage earnings and social security tax payments are not available to us. Thus, we use instead data reported in published sources. The basis for our analysis is the Basic Wage Survey by the Ministry of Labor. This survey is published annually, and each firm submits a report with data indicating the average worker's wage, age, years of work experience at the particular firm, and education as well as firm size, occupation, and industry. We apply the average monthly wage of a worker in the following way.

We present a typical Japanese household, headed by a man age sixty-five in 1995 (born on 1 April 1930 as the social security data are collected on a fiscal year basis, i.e., from April to March in the following year, in Japan) whose wife was born in 1933 and has no work experience. He is a high school graduate (as are about 50 percent of the male employees in 1995) and worked in the same firm from age twenty until the normal retirement age of sixty. At age sixty, he left that firm and started to work in another. We assume that he worked fulltime in both firms. The couple's children are already grown and are now economically independent. This household head works for a typical Japanese company and is covered by the Kosei Nenkin Hoken (KNH) plan, the largest public pension scheme for private-sector employees (covering 85 and 71 percent of contributors among wage earners and beneficiaries, respectively). 
There are other public pensions for employees in the public sector and specific groups of the private sector with different pension contributions and benefits schemes, but these are not considered here. Our household head is eligible for three components of $\mathrm{KNH}$ : the basic component, the earnings-related component, and the additional component for a dependent wife. Firm pensions and private pensions are not considered here.

On the basis of the assumptions outlined above, the following steps are necessary to compute social security wealth, which is the expected net present value of social security benefits through the individual's lifetime.

First, we derive the wage profile of a typical worker whose characteristics are given above. Since panel data are not available, we simply assume that the historical wage profile of an individual traces the same wage profile pattern in a given year adjusted by inflation, which is the same method taken by Seike (1993).

Second, the wage data contained in the Basic Wage Survey are adjusted to the scales of the standard wages on which the pension premium and benefits are based. The monthly social security benefits are the sum of the following components: (1) a fixed component, which is a certain unit price multiplied by the number of years worked, set at a maximum of 444 months; (2) years of contributions (which do not account for years of unemployment); (3) the base wage rate; and (4) an adjustment for a dependent spouse.

Third, the pension premium is imposed on the base wage, which is monthly wages including overtime payments but excluding bonuses. Thus, the wage data contained in the Basic Wage Survey are adjusted to a pension premium basis. In addition, the adjusted wage profiles are deflated by the historical wage series in the Ministry of Labor's Maitsuki Kinrotokei Chousa (Survey of Monthly Wages). We add both the employee's and the employer's share of the pension premiums, under the assumption that the employer's share is fully borne by the worker, for example, in the form of lower wages.

Using these procedures, we derive social security wealth ( $\mathrm{SSW}$ ), social security accrual (SSA), and taxes/subsidies, explaining the worker's retirement incentives. The average life expectancy is based on the Japan life tables from the Population Research Institute, Ministry of Health and Welfare, adjusting for the sex/age-specific mortality rate. Note that we use the "unconditional mortality risk" beyond age fifty-five, which is tantamount to disregarding the probability of death at each year after the fifty-fifth birthday." We use this unconditional mortality assumption because, at the time of the computation of social security wealth, it is reasonable to base an analysis on the perspective of the forward-looking individual who, at age fifty-four, is considering retirement incentives at all future ages. In the base case, we use a real discount rate of 3 percent.

11. An alternative assumption is to vary the conditional mortality risk on the basis of the year of retirement. 


\subsubsection{Social Security Wealth}

Social security wealth is the net discounted sum of lifetime pensions and other benefits at age fifty-five. We subtract the pension premiums that the individual would pay during any continued work and compute an expected net present value of social security wealth. Social security wealth is the sum of the expected pension benefits not only to an individual but also to his spouse, including the zaishoku (earlier retirement) pension, the full pension at age sixty-five, the addition for dependent spouses, survivor benefits, and the individual basic pension for dependent spouses aged sixty-five and over. The last benefit needs some additional explanation, since a dependent spouse is eligible for the basic pension on her own and it is not paid to the household head. Nevertheless, we include the pension benefits of the dependent spouse when determining the social security wealth of the household head as we did with survivor benefits. In addition, wage subsidies are added to social security wealth after the 1994 reform.

Comparing the discounted values of social security wealth at different ages, however, is not enough to predict the retirement decision. The accrual rate for work in a given year, which is the change in the worker's future social security benefits relative to what he would earn over the coming year, also figures in an individual's decision whether to work another year. Thus, social security accrual is defined as the difference in social security wealth: $\mathrm{SSA}_{t}=\mathrm{SSW}_{\text {, }}$ SSW t-1 .

Social security accrual is presented as a ratio, that is, the percentage change in social security wealth. Also, the change in social security wealth (i.e., social security accrual) relative to projected earnings over that year is defined as a tax/subsidy rate. If the change in social security wealth associated with an additional year of work is negative, the effect is that of a tax on work. If the change is positive, the effect is that of a subsidy to work.

\subsubsection{Specific Characteristics of Retirement Incentives in Japan}

The following two points about labor market conditions must be taken account of in any discussion of the retirement incentives of older persons in Japan. First, after retirement at age sixty, the wages of older persons tend to fall substantially - by 40 percent, on average - from the preretirement level. This is mainly because wages in the primary firm - the "internal labor market"are seniority based while those with the new firm-the "external market"are close to flat. Thus, unlike in the United States, the preretirement wage is not a realistic reference for the opportunity costs of one's retirement. We assume that this diminishing wage profile (which older persons over age sixty actually face) reflects the actual labor market situation in the base-case simulation.

Second, older persons between the ages of sixty and sixty-four can claim the zaishoku pension, and these benefits are dependent on wages. When wages 
are sufficiently low, the individual can receive both wages and pension benefits, subject to an earnings test. Thus, when deciding to work at that age, the individual compares a full-time wage, on the one hand, with a part-time wage and pension benefits, on the other. Also, at age sixty-five and beyond, individuals are eligible to receive a full pension with no earnings criteria; that is, full pension benefits are unconditional, and no premium is required.

\subsubsection{The Base Case}

The results of the base-case simulation are summarized in table 6.1. Each row represents the age of the worker in the last year he works. For example, the row for age fifty-four represents the effect of working until age fifty-four and retiring on the fifty-fifth birthday.

The first column shows the replacement rate, which is conventionally defined as the ratio of pension benefits to preretirement wage earnings. This concept is irrelevant until the worker can actually claim pension benefits, which occurs when his last year of work is fifty-nine and he retires on his sixtieth birthday. When he becomes eligible to claim a pension, the replacement rate is about 55 percent. This rate jumps to 80 percent in his sixtieth year because the preretirement wage-the denominator of the replacement rate-drops substantially after the mandatory retirement age of sixty.

The large drop in the replacement rate at age sixty-four is due to the fact that, after the sixty-fifth birthday, pension benefits are not conditional on an earnings test and the worker need not pay any pension premiums. He will see a small jump in the rate in his sixty-seventh year, when his wife, who is three years his junior, becomes eligible for her basic pension benefit.

Table 6.1

Base-Case Incentive Calculations

\begin{tabular}{lccccc}
\hline $\begin{array}{l}\text { Last Year } \\
\text { of Work }\end{array}$ & $\begin{array}{c}\text { Replacement } \\
\text { Rate }\end{array}$ & $\begin{array}{c}\text { SSW } \\
\text { (thousand yen) }\end{array}$ & $\begin{array}{c}\text { Accrual } \\
\text { (thousand yen) }\end{array}$ & $\begin{array}{c}\text { Accrual } \\
\text { Rate }\end{array}$ & $\begin{array}{c}\text { Tax/ } \\
\text { Subsidy }\end{array}$ \\
\hline 54 & $\ldots$ & 33,490 & $\ldots$ & $\ldots$ & $\ldots$ \\
55 & $\ldots$ & 34,106 & 616 & .018 & -.195 \\
56 & $\ldots$ & 34,734 & 628 & .018 & -.202 \\
57 & $\ldots$ & 35,058 & 324 & .009 & -.106 \\
58 & $\ldots$ & 35,390 & 333 & .009 & -.112 \\
59 & .552 & 35,662 & 272 & .008 & -.138 \\
60 & .800 & 35,018 & -644 & -.018 & .338 \\
61 & .799 & 34,396 & -622 & -.018 & .340 \\
62 & .802 & 33,792 & -603 & -.018 & .342 \\
63 & .801 & 33,208 & -584 & -.017 & .340 \\
64 & .438 & 32,719 & -489 & -.015 & .204 \\
65 & .549 & 32,719 & 0 & 0 & 0 \\
66 & .547 & 32,719 & 0 & 0 & 0 \\
67 & .716 & 32,719 & 0 & 0 & 0 \\
68 & .608 & 32,719 & 0 & 0 & 0 \\
69 & .607 & 32,719 & 0 & 0 & 0 \\
\hline
\end{tabular}


The next three columns show the evolution of social security wealth over time. If the worker retires on his sixtieth birthday, the net present value of his social security wealth would be $¥ 35.7$ million. Social security wealth increases up to his sixtieth birthday because he cannot claim any benefits until then. If he works another year, however, social security wealth falls by 1.8 percent. Thus, for this individual, the public pension system is "actuarially unfair" as it penalizes work beyond age sixty by reducing future social security benefits. Social security wealth is unchanged beyond age sixty-five because, as mentioned above, there are no more contributions or opportunity costs for postponing retirement.

Social security accrual is the change in social security wealth from the previous period. Between the ages of fifty-five and fifty-nine, social security accrual is positive - an additional year of work gradually raises social security wealth with longer contribution periods, and this exceeds the negative effects of additional pension premiums. However, as the worker is eligible for the zaishoku pension benefits from age sixty, additional work until age sixty-four incurs the opportunity costs of a delay in claiming the benefits. In addition, the higher the earnings received, the more the pension benefits are reduced. For example, the benefits of the base-case worker are reduced by half. As a result, the social security accrual rate is negative; there is roughly a 2 percent decline in social security wealth each year due to continued work. Social security accrual becomes zero beyond age sixty-five, reflecting no change in social security wealth.

The final column shows the tax/subsidy rate. The tax/subsidy rate is the ratio of change in social security wealth to projected earnings over that year. The negative sign here indicates a subsidy, implying that a worker receives more than an actuarial adjustment for delaying his benefit claims and paying additional pension premiums. The worker keeps getting subsidies to work through his sixtieth birthday, but, beyond that point, he is forced to pay taxes on work through age sixty-four. This is because he loses social security benefits by continuing to work; besides, the pension benefits of most individuals are not taxed, while wages are. If a worker decides to work between the ages of sixty and sixty-four, forgone social security wealth amounts to nearly one-third of a year's earnings. This significant shift from subsidy to tax at age sixty is a major cause of the large drop in labor force participation. There is, however, no such tax disincentive effect beyond age sixty-five.

\subsubsection{Other Cases}

Table 6.2 shows these results for a single worker. The negative effect of delayed retirement is larger for a single than for a married worker. This is mainly because the single worker has no survivors and receives no other benefits for a dependent spouse (even though the premiums paid are equal given the same earnings). The social security wealth of a single worker at age fiftynine is $¥ 21.9$ million, 39 percent less than that of a married worker. Neverthe- 


\begin{tabular}{lccccc} 
Table 6.2 & \multicolumn{6}{c}{ Incentive Calculations-Single Worker } \\
\hline $\begin{array}{l}\text { Last Year } \\
\text { of Work }\end{array}$ & $\begin{array}{c}\text { Replacement } \\
\text { Rate }\end{array}$ & $\begin{array}{c}\text { SSW } \\
\text { (thousand yen) }\end{array}$ & $\begin{array}{c}\text { Accrual } \\
\text { (thousand yen) }\end{array}$ & $\begin{array}{c}\text { Accrual } \\
\text { Rate }\end{array}$ & $\begin{array}{c}\text { Tax/ } \\
\text { Subsidy }\end{array}$ \\
\hline 54 & $\ldots$ & 20,350 & $\ldots$ & $\ldots$ & $\ldots$ \\
55 & $\ldots$ & 20,840 & 490 & .024 & -.158 \\
56 & $\ldots$ & 21,338 & 498 & .024 & -.163 \\
57 & $\ldots$ & 21,529 & 191 & .009 & -.064 \\
58 & $\ldots$ & 21,727 & 198 & .009 & -.069 \\
59 & .516 & 21,864 & 137 & .006 & -.071 \\
60 & .751 & 21,164 & -700 & -.032 & .376 \\
61 & .751 & 29,483 & -681 & -.032 & .381 \\
62 & .754 & 19,821 & -662 & -.032 & .384 \\
63 & .753 & 19,178 & -643 & -.032 & .383 \\
64 & .425 & 18,630 & -548 & -.029 & .244 \\
65 & .541 & 18,630 & 0 & 0 & 0 \\
66 & .538 & 18,630 & 0 & 0 & 0 \\
67 & .536 & 18,630 & 0 & 0 & 0 \\
68 & .534 & 18,630 & 0 & 0 & 0 \\
69 & .532 & 18,630 & 0 & 0 & 0 \\
\hline
\end{tabular}

less, the difference in social security accrual between the married and the single individual is not very significant. This is due mainly to the fact that, while the social security wealth of the married worker at age sixty is much larger than that of a single worker, the change in social security benefits by working another year is almost exactly the same for the married and the single individual since the additional benefit for a spouse is largely fixed. The larger tax on the single worker, however, indicates that he will lose more from his decision to continue work than his married counterpart.

The incentive mechanism varies by wage level. Tables 6.3 and 6.4 show the effects of considering different earning histories for a married worker: We compare a worker at the ninetieth percentile of the earnings distribution (table 6.3) with a worker at the tenth percentile (table 6.4).$^{12}$ According to tables 6.3 and 6.4, the replacement rate is higher for the low-earnings worker. Also, the tax rate on the low-wage earner is twice that of the high-wage earner. This implies the redistributional mechanism in the basic pension (the fixed component), through which the low-wage earner loses more relative to his wage earnings by postponing retirement than does the high-wage earner.

Table 6.5 considers a different permutation to the earnings history for a worker who has an incomplete earnings history. Compared with the base case, where the worker has contributed for forty years at age sixty, the worker in this case is assumed to have started working five years later; he therefore needs to work an additional five years to be eligible for full pension benefits. According

12. Wages for these workers are obtained from the 1994 age/earnings profile. 
Table 6.3

Incentive Calculations-Ninetieth Percentile Earnings

\begin{tabular}{lccccc}
\hline $\begin{array}{l}\text { Last Year } \\
\text { of Work }\end{array}$ & $\begin{array}{c}\text { Replacement } \\
\text { Rate }\end{array}$ & $\begin{array}{c}\text { SSW } \\
\text { (thousand yen) }\end{array}$ & $\begin{array}{c}\text { Accrual } \\
\text { (thousand yen) }\end{array}$ & $\begin{array}{c}\text { Accrual } \\
\text { Rate }\end{array}$ & $\begin{array}{c}\text { Tax/ } \\
\text { Subsidy }\end{array}$ \\
\hline 54 & $\ldots$ & 39,031 & $\ldots$ & $\ldots$ & $\ldots$ \\
55 & $\ldots$ & 39,777 & 746 & .019 & -.150 \\
56 & $\ldots$ & 40,545 & 768 & .019 & -.157 \\
57 & $\ldots$ & 41,018 & 472 & .012 & -.099 \\
58 & $\ldots$ & 41,507 & 489 & .012 & -.105 \\
59 & .425 & 41,907 & 400 & .010 & -.129 \\
60 & .618 & 41,178 & -729 & -.017 & .244 \\
61 & .620 & 40,469 & -709 & -.017 & .247 \\
62 & .624 & 39,777 & -692 & -.017 & .250 \\
63 & .625 & 39,104 & -673 & -.017 & .251 \\
64 & .391 & 38,575 & -529 & -.014 & .156 \\
65 & .478 & 38,575 & 0 & 0 & 0 \\
66 & .476 & 38,575 & 0 & 0 & 0 \\
67 & .595 & 38,575 & 0 & 0 & 0 \\
68 & .527 & 38,575 & 0 & 0 & 0 \\
69 & .526 & 38,575 & 0 & 0 & 0 \\
\hline
\end{tabular}

Table 6.4

Incentive Calculations-Tenth Percentile Earnings

\begin{tabular}{lccccc}
\hline $\begin{array}{l}\text { Last Year } \\
\text { of Work }\end{array}$ & $\begin{array}{c}\text { Replacement } \\
\text { Rate }\end{array}$ & $\begin{array}{c}\text { SSW } \\
\text { (thousand yen) }\end{array}$ & $\begin{array}{c}\text { Accrual } \\
\text { (thousand yen) }\end{array}$ & $\begin{array}{c}\text { Accrual } \\
\text { Rate }\end{array}$ & $\begin{array}{c}\text { Tax/ } \\
\text { Subsidy }\end{array}$ \\
\hline 54 & $\ldots$ & 29,547 & $\ldots$ & $\ldots$ & $\ldots$ \\
55 & $\ldots$ & 30,082 & 535 & .018 & -.276 \\
56 & $\ldots$ & 30,622 & 540 & .018 & -.283 \\
57 & $\ldots$ & 30,853 & 230 & .008 & -.123 \\
58 & $\ldots$ & 31,087 & 235 & .008 & -.129 \\
59 & .772 & 31,283 & 196 & .006 & -.143 \\
60 & .982 & 30,713 & -571 & -.018 & .430 \\
61 & .981 & 30,163 & -549 & -.018 & .432 \\
62 & .985 & 29,633 & -531 & -.018 & .434 \\
63 & .982 & 29,121 & -512 & -.017 & .432 \\
64 & .474 & 28,676 & -444 & -.015 & .241 \\
65 & .606 & 28,676 & 0 & 0 & 0 \\
66 & .604 & 28,676 & 0 & 0 & 0 \\
67 & .825 & 28,676 & 0 & 0 & 0 \\
68 & .669 & 28,676 & 0 & 0 & 0 \\
69 & .669 & 28,676 & 0 & 0 & 0 \\
\hline
\end{tabular}

to this table, the tax for working an additional year at ages sixty to sixty-four is less for the worker with an incomplete earnings history.

Figure 6.13 shows the time-series pattern of taxes on/subsidies to continued work for the base case and these two permutations of the different earnings histories. The subsidy is larger for the low-wage earner at ages under sixty. From age sixty to age sixty-four, there is a substantial tax on an additional year 
Table 6.5

\begin{tabular}{lccccc}
\hline $\begin{array}{l}\text { Last Year } \\
\text { of Work }\end{array}$ & $\begin{array}{c}\text { Replacement } \\
\text { Rate }\end{array}$ & $\begin{array}{c}\text { SSW } \\
\text { (thousand yen) }\end{array}$ & $\begin{array}{c}\text { Accrual } \\
\text { (thousand yen) }\end{array}$ & $\begin{array}{c}\text { Accrual } \\
\text { Rate }\end{array}$ & $\begin{array}{c}\text { Tax } \\
\text { Subsidy }\end{array}$ \\
\cline { 1 - 2 } 54 & $\ldots$ & 22,218 & $\ldots$ & $\ldots$ & $\ldots$ \\
55 & $\ldots$ & 22,689 & 471 & .021 & -.197 \\
56 & $\ldots$ & 23,175 & 486 & .021 & -.189 \\
57 & $\ldots$ & 23,682 & 506 & .022 & -.201 \\
58 & $\ldots$ & 24,194 & 512 & .022 & -.209 \\
59 & .409 & 24,664 & 470 & .019 & -.276 \\
60 & .581 & 24,533 & -131 & -.005 & .079 \\
61 & .591 & 24,385 & -148 & -.006 & .093 \\
62 & .603 & 24,219 & -166 & -.007 & .107 \\
63 & .612 & 24,122 & -96 & -.004 & .063 \\
64 & .387 & 24,084 & -39 & -.002 & .020 \\
65 & .460 & 24,084 & 0 & 0 & 0 \\
66 & .458 & 24,084 & 0 & 0 & 0 \\
67 & .665 & 24,084 & 0 & 0 & 0 \\
68 & .546 & 24,084 & 0 & 0 & 0 \\
69 & .545 & 24,084 & 0 & 0 & 0 \\
\hline
\end{tabular}

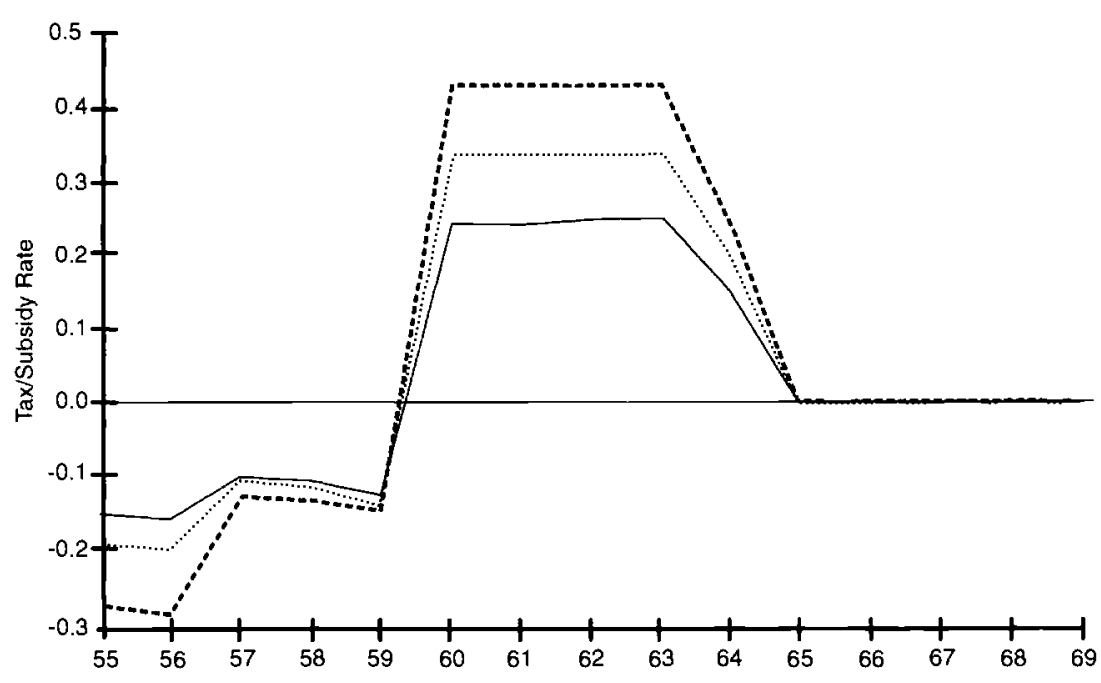

Fig. 6.13 Tax/subsidy rates across earnings profiles 
Table 6.6

Incentive Calculations-Summary of Other Cases for Last Year of Work Is Age 60

\begin{tabular}{lccccc}
\hline Case & $\begin{array}{c}\text { Replacement } \\
\text { Rate }\end{array}$ & $\begin{array}{c}\text { SSW } \\
\text { (thousand } \\
\text { yen) }\end{array}$ & $\begin{array}{c}\text { Accrual } \\
\text { (thousand } \\
\text { yen) }\end{array}$ & $\begin{array}{c}\text { Accrual } \\
\text { Rate }\end{array}$ & $\begin{array}{c}\text { Tax/ } \\
\text { Subsidy }\end{array}$ \\
\hline Base case & .800 & 35,018 & -644 & -.018 & .338 \\
Single worker & .751 & 21,164 & -700 & -.032 & .376 \\
90th percentile & .618 & 41,178 & -729 & -.017 & .244 \\
10th percentile & .735 & 30,169 & $-1,257$ & -.040 & .671 \\
Incomplete history & .581 & 24,533 & -131 & -.005 & .079 \\
\hline
\end{tabular}

of work on the small base of earnings at the tenth percentile. Also, table 6.6 summarizes various incentive calculations.

\subsection{Country-Specific Issues}

\subsubsection{Lump-Sum Severance Payments}

In Japan, one can get a substantial amount in severance payments when leaving a company. For example, a typical college graduate working at the same firm for thirty-five years receives a lump-sum payment equivalent to forty-eight months of wages in 1994, which is partly substitutable with the firm's pension. Usually, the amount increases with more years of service up to a certain number of years. However, the increase in the lump-sum payments becomes marginal when the worker is in his fifties, and the net gain from it declines over time. Many Japanese firms encourage earlier retirement by increasing lumpsum payments with a rate of the increase that declines with age. Also, they give higher payments to those employees who voluntarily leave the firm before the normal retirement age (Seike 1997).

\subsubsection{Wage Subsidies}

Another social insurance benefit that potentially interacts with the public pension program is the wage subsidies to working older persons, a program established in 1994 as part of the unemployment insurance scheme. The wage subsidy program intends to shift the recipients of unemployment insurance; beginning at age sixty, one can be eligible for a wage subsidy for as long as five years, compared to the maximum three hundred days for which older people can receive unemployment insurance. These subsidies of 25 percent of the current wage $\left(W_{t}\right)$ are provided to those who are aged sixty to sixty-four years and receive a wage that is at least 15 percent lower than their wage at the (normal retirement) age of sixty $\left(W_{0}\right)$, subject to a certain wage ceiling. ${ }^{13}$

13. The wage subsidy program was introduced in order to encourage older persons who receive unemployment compensation to work. 
Wage subsidies (sub) to these older workers are determined on the basis of the following formulas:

$$
\begin{aligned}
\text { sub } & =0.25 \times W_{t} \text { for } W_{t}<0.64 \times W_{0}, \\
& =\left(13.6 \times W_{0}-16 W_{t}\right) / 21 \text { for } 0.64 \times W_{0}<W_{t}<0.85 \times W_{0}, \\
& =0 \text { for } 0.85 \times W_{0}<W_{t} .
\end{aligned}
$$

The first formula is the one that potentially applies to most older persons as their wages after mandatory retirement fall by about half on average.

The wage subsidy program is an entirely different scheme from the public pension, but its economic implications are similar to those of the zaishoku pensions for those aged sixty to sixty-four. Both are available to the same age group and are subject to certain earnings criteria, thus affecting retirement decisions. We treat this wage subsidy in the same way as we do pension premiums; both affect social security wealth, though in opposite directions. As the wage subsidy of 25 percent well exceeds the employee's share of pension premiums ( 8.25 percent), the combined effects would increase the net public pension assets of an individual.

\subsubsection{Effects of the 1994 Pension Reform}

In Japan, there was a major revision of the public pension scheme as well as of employment insurance in 1994. These two reforms are expected to have a desirable effect on work incentives for the elderly. First, the reform in the zaishoku (on-the-job) pension has lowered the "tax effect" on work for those aged sixty to sixty-four. Roughly speaking, after the 1994 reform, the worker with an additional two dollars in earnings will lose one dollar of pension benefits, instead of the two dollars he would have lost before the reform. Second, the wage subsidy equivalent to 25 percent of wage earnings is given to the same age group up to a certain ceiling of earnings. However, the wage subsidies are scheduled to be revised in 1998: for those who receive both a wage subsidy and pension benefits, an amount equivalent to 10 percent of wages is to be deducted from the pension benefits. We have already accounted for this revision in our calculations of taxes/subsidies after the 1994 reform.

As a result of the 1994 reform, the tax rate for an individual working an additional year at age sixty is estimated to have been lowered to approximately one-third of the prereform level (see table 6.7 as well as fig. 6.14). These two reforms in the social insurance schemes should reduce the disincentive effect of the public pension and stimulate the labor force participation of older persons.

\subsection{Conclusion}

This study reveals the incentive mechanism whereby the public pension affects the retirement decisions made in the Japanese labor market, a mechanism 
Table 6.7

Base-Case Incentive Calculations (after 1994 reform)

\begin{tabular}{lccccc}
\hline $\begin{array}{l}\text { Last Year } \\
\text { of Work }\end{array}$ & $\begin{array}{c}\text { Replacement } \\
\text { Rate }\end{array}$ & $\begin{array}{c}\text { SSW } \\
\text { (thousand yen) }\end{array}$ & $\begin{array}{c}\text { Accrual } \\
\text { (thousand yen) }\end{array}$ & $\begin{array}{c}\text { Accrual } \\
\text { Rate }\end{array}$ & $\begin{array}{c}\text { Tax/ } \\
\text { Subsidy }\end{array}$ \\
\hline 54 & $\ldots$ & 33,490 & $\ldots$ & $\ldots$ & $\ldots$ \\
55 & $\ldots$ & 34,053 & 563 & .017 & -.182 \\
56 & $\ldots$ & 34,629 & 575 & .017 & -.188 \\
57 & $\ldots$ & 34,901 & 272 & .008 & -.091 \\
58 & $\ldots$ & 35,184 & 283 & .008 & -.097 \\
59 & .562 & 35,655 & 472 & .013 & -.187 \\
60 & .624 & 35,412 & -244 & -.007 & .100 \\
61 & .627 & 35,164 & -248 & -.007 & .106 \\
62 & .628 & 34,911 & -253 & -.007 & .113 \\
63 & .633 & 34,649 & -263 & -.008 & .117 \\
64 & .409 & 34,267 & -381 & -.011 & .159 \\
65 & .549 & 34,267 & 0 & 0 & 0 \\
66 & .547 & 34,267 & 0 & 0 & 0 \\
67 & .716 & 34,267 & 0 & 0 & 0 \\
68 & .608 & 34,267 & 0 & 0 & 0 \\
69 & .607 & 34,267 & 0 & 0 & 0 \\
\hline
\end{tabular}

- Before the 1994 Reform $-\triangle \quad$ After the 1994 Reform

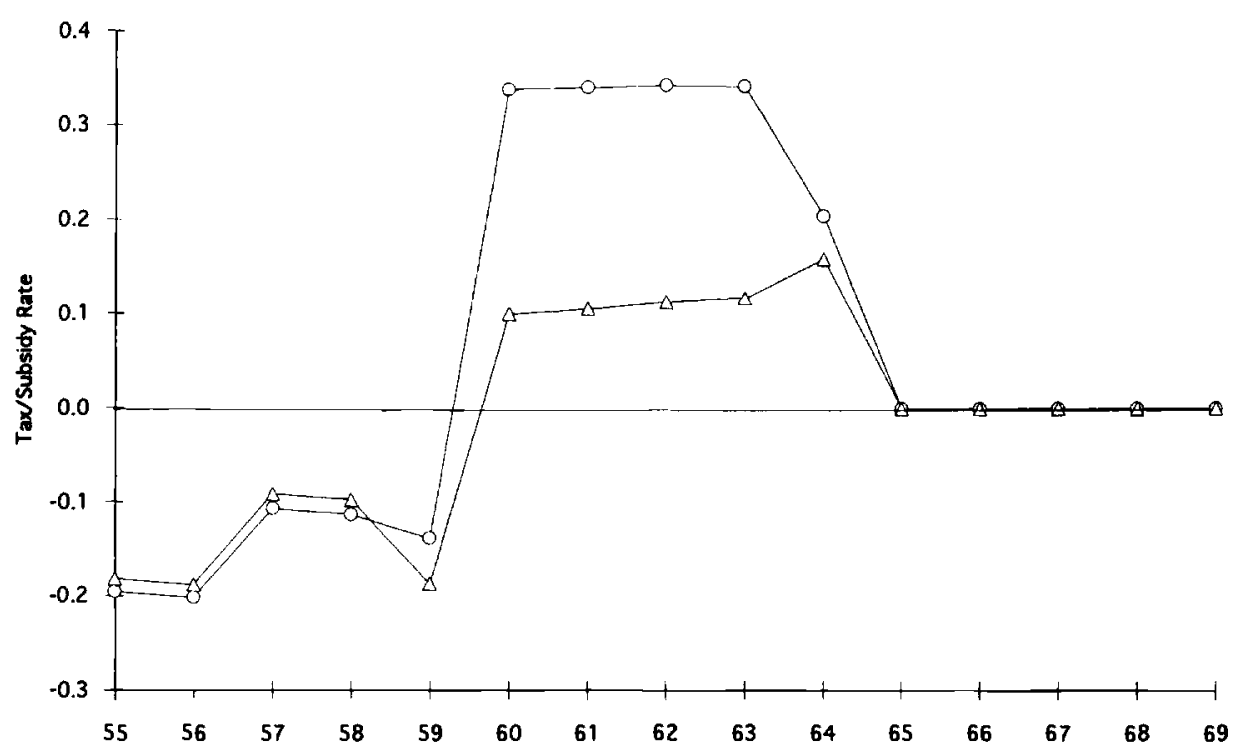

Fig. 6.14 Tax/subsidy rates before and after the 1994 reform 
that has much in common with those in the United States and other OECD countries. Pension benefits are designed to be "actuarially unfair," and the decision to work between the ages of sixty and sixty-four is penalized. As the population is aging rapidly, it is wasteful to maintain such a disincentive mechanism. This study indicates the need to reform the public pension scheme to restore an actuarially fair principle.

Even given the disincentive effect outlined above, the labor market participation of older Japanese persons is quite high by international standards, and the trend toward earlier retirement has changed recently. This is partly due to the fact that there are a significant number of self-employed persons in their sixties in the labor market. Also, the sustained demand for labor should have helped raise the labor force participation rate of older persons. But the fact that the public pension is designed on more generous lines in Japan than in other industrialized countries is also important; for example, after age sixty-five, no more contributions or any earnings tests are required to determine eligibility for benefits. This partly explains why the labor market participation rate of older Japanese persons is high. The 1994 pension reform, which both mitigates the tax effect on the earlier retirement pension scheme and introduces a wage subsidy scheme, would further reduce the size in the expected loss in social security wealth with continued work between the ages of sixty and sixty-four, thus possibly stimulating older persons to work.

\section{References}

Higuchi, Yoshio. 1995. Sengyoushufu hogoseisaku no keizatekikiketsu (Economic consequences of the policy protecting nonworking housewives). In Jyakusha hogo seisakuno keizai bunseki (Economic analysis of the protection of the so-called economically disadvantaged), ed. Tatsuo Hatta and Naohiro Yashiro. Tokyo: Nihonkeizaishinbunsha.

Seike, Atsushi. 1993. Koureika sakaino roudoushijyo (The labor market in an aging society). Tokyo: Toyokeizai shimposha.

- 1997. Labor market implications of social security: Company pension plans, public pensions, and retirement behavior of the elderly in Japan. In The economic effects of aging in the United States and Japan, ed. Michael Hurd and Naohiro Yashiro. Chicago: University of Chicago Press.

Tachibanaki Toshiaki and Shimono Keiko. 1994. Kojinchochikuto raifusaikuru (Savings and the life cycle). Tokyo: Nihonkeizaishimbunsha.

Takayama Noriyuki. 1992. The graying of Japan: An economic perspective on public pensions. Tokyo: Kinokuniya; Oxford: Oxford University Press.

Ward, M. P. 1984. The effect of social security on male retirement behavior. Santa Monica, Calif.: Rand Corp.

Yashiro, Naohiro. 1997. Economic position of the elderly in Japan. In The economic effects of aging in the United States and Japan, ed. Michael Hurd and Naohiro Yashiro. Chicago: University of Chicago Press. 